\title{
Philosophy of History: Challenges to Truth
}

\author{
Busharat Elahi Jamil
}

\begin{abstract}
Philosophy of History is to expedite and evaluate the intellect originated by the sounded historical resources. Philosophical 'Doctrines' and 'Scholarships' by the influential philosophers, thinkers and theorists immensely examined and determined the historical facts. Various historical discourses, methodologies and experiments decorated the historiography to provide new approaches and philosophical observations. Historical data, primary and secondary resources and scientific approaches are to measure the validity of historical means. Historiography endorses and accepts the different methods of philosophy of history. But the inquiry of a historian gives the historical facts a new philosophical approach and understandable thinking to the readers. Actually philosophy of history is a science to measure the historical resources. It is to combine the binary approaches of historical philosophers and certain historians to define the results and applications of the past "which still living in the present". Philosophy of History bent the historical truth to visualize the past in the present. Philosophical expressions provided the actual strength to historical data to compel the false historical approaches. Philosophical approaches more authenticate the factual resources and focus on the temporal views of available data.
\end{abstract}

Index Terms-Philosophy of history, resources, research, historiography, historians.

\section{Challenges to TRUTH}

In the portfolio of 'History', the interests of scholars, intellectuals and Historians determine the contemporary legitimacy of Philosophy of History. Their sufficient interactions with historical conceptualization furthermore, endorses the ideas and the notions of survived domain of History. Certain experimental and investigational subjects elaborate and refurbish the evolving idea of history. The intelligence of the historians is ever based on the existing obtainable resources. They experience their doctrines through configuration of the historical approaches; facts and inclined impacts. When an independent historian [1] elucidates the historical events, he deals with the philosophical intentions and ideologies to reach a final outcome or conclusion.

After the investigation of the evidences, an independent historian creates a bridge between truth ad realities. This phenomenon configures the gravity of the interpreted theoretical fame-work of the past events. Initially, a historian tentatively designates the primary and secondary resources along with accessible facts. He furthermore, establishes "a provisional interpretation in the light of which that selection has been made-by others as well as by himself" [2]. These steps are worthy to interlink as well as to understand past and present the logical influence leading to

Manuscript received January 10, 2018, revised April 9, 2018.

Busharat Elahi Jamil is with the Government College University Lahore, Pakistan (email: busharathistorian@gmail.com). certainty of the past events. So, "the historian and the facts of history are necessary to one another" [3] to necessitate the behaviours of the past. Moreover, this is also the duty of a historian to analyze the past by judging its "moral content" under certain available evidences [4].

History provides an ending view and constructs a possible explanation to set up certain "events taken to be possible causes”. Paul A Roth [5] more explains that “... what creates the event to be explained resides in the interests of the historian..." [6] The description determines that a historian's aptitude counts when he raises the historically marked 'research questions'. These questions are generated by reviewing available historical data, context and text. Finally, in the conclusion of his/her research, a historian tries to answer questions which are delimited by an argument of certain research paradigm.

Some historians deal with the historical proceedings in a different way as they pretend that the historical events are 'problematize'. Definitely, it is somehow difficult to analyze and conjugate the occurring events. In order to avoid such quandaries, sometimes they treat the historical events as only 'narratively' with a significant advance historical philosophy. This gesture could disturb or cause misunderstandings between the readers and historical researchers. Analytical and philosophical approaches towards historical data and facts could be more helpful to eliminate extra and useless unconfirmed historical matter from resources. This course fortifies the historical connectivity and explicates the rationale of the historical truth which could be helpful to advance the historical progression.

Laws and rules regarding the "Historical Development", William Turner called "Posteriori Laws". Such 'Laws' are formed on the basis of certain primary principles but established and bestowed by the course of "Inductive Reasoning”. Turner more elaborates that [7]:

"This does not mean that history is the resultant of forces acting capriciously, but that the forces which produce historical development — being dependent on physical conditions, mental temperament, and the action and interaction of social institutions, customs, and organizations - are contingent, not necessary causes ; that consequently the philosophy of history is not a geometry of the evolution and play of such forces ; and that the laws which it seeks to establish are not deductions from definitions and axioms, but generalizations, similar to the post facta generalizations of the statistician”.

Historically, in social sciences the results might vary, even in some cases a historian cannot reach an absolute decision particularly when the 'continuity' of the history is disturbed. In contrast, in natural sciences the methodology is quite opposite because the data is in calculated form and its analysis is comparatively less difficult than the historical 
phenomenon. Moreover, a deficiency in the scientific method ensues that scientific approaches cannot establish the basic objectives of relevant studies. Scientific studies are bound to general and precise manners [8]. Historical developments in course of philosophy of history captivate the natural affluence of the historical gains. Philosophical analysis assures to eradicate the hindrances concerning the philosophical observations of the past events.

Philosophy of history fixes certain areas of inquiry but its interactive validity is a controversial phenomenon. Mostly, “...the argument offered for or (more often) against its very possibility are many" [9]. History must be analyzed/examined under the concrete reality of past events. The result of historical events does not matter when such events acquire or prove the cognitive perspective of the past. The validity of the proven truth is analyzed upon the ongoing chronological proceedings. Historians have their own view point, intellect and rational which varied and remain under the influence of a certain developing course of life. Therefore, in the past any established historical scholarship is likely to be replaced with a new criticism or anti-thesis in future.

Philosophy of History justifies and rationalizes the prevailing historical evidences to patch between the historical truths adequately and fairly. This enquiry should deal directly to the subject matter to reach conclusions regarding historical studies. "Thus when an historian reads a statement in one or other of the 'original sources' for a period he is studying, he does not automatically accept it. His attitude to it, if he knows his job, is always critical: he has to decide whether or not to believe it, or again how much of it to believe" [10]. Historian is not the person who creates or establishes these resources as he only to evaluate or examine the resources. He needs to be critical having the eligibility to accept or reject the resources wholly or partially [10].

Nevertheless, historical resources have some concerns particularly the dogma of the political monarchs is ever dominant, particularly in the colonial age as colonial forces always tried to manoeuvre the natives. It at all times influences and over-comes the colonial periphery and its inhabitants. They tend to create a distinctive class to submit colonial policies. In this vision, they try to distract the historical discourses of the colonized peoples. This firm occurrence can disrupt the embryonic process of historical philosophy because of on-going clash of monopolization by the colonizer. They can adeptly modify and exploit numerous historical data. Colonial rulers also alter and subjugate the various historical methods in the colony to manipulate the system in order to prolong their decree. This can produce enormous conflicts in the native philosophical approaches of historical illuminations.

Sometimes, Historical facts are either subtle or not clear, which are directly concerned with a religion or culture of a certain society. The interpretations of such facts by experts and responsible can possibly damage the value and validity of historical evidences of a synthesis. Since, culture has ever been dominant over religion, the opinion and descriptions of the concerned experts of provinces can be diverged. This phenomenon distracts the understanding of the reader and his/her verdict on certain historical facts.
According to the W. H. Walsh [10]:

"We can sum this up by saying that it is the duty of the historian not only to base all his statements on the available evidence, but further to decide what evidence is available. Historical evidence, in other words, is not an ultimate datum to which we can refer to test the truth of historical judgments. But this, as will be obvious, reopens the whole question of fact and truth in history".

E. H. Carr (1892-1982) [11] deliberated the 19th Century as the 'age of facts', Gradgrind believed about historical facts that "facts alone are wanted in life". Likewise, Ranke remarked, "task of the historian was simply to show how it really was" [12].

In societies, where the history of that particular society does not place any distinguish role, "the stories are told, songs and dances and rituals are performed, telling of the past glories and sufferings of the group...through this history the identification of individuals with the group are deepened."[13] However, meticulously this philosophy to interpret a designated affiliation can intrude the chorological order of occurred events as well as available data. In future, the progress of History would observed intellectually because of its analysis by various measures. In truth, History directly influences human ideas, analyzes past and makes compatibility with the future.

Every available primary and secondary data represents certain domain, event and topic from the past. Nevertheless, events are interlinked, so a historian cannot neglect any source of accessible information. Even a single source of data can ascertain and clarify many past events. On the other hand, W. B. Gallie (1912-1998)[14] underlined "Critical Philosophy" of the History in his work 'Philosophy and the Historical Understanding' commenting that 'critical philosophy' of history is overstrained and suffering from various terminologies, groupings of problems, different methods, approaches, etc. since Greece times. He focused, "if it is a claim to understand what is particular about particular cases, it is directed on to what is, in the nature of things un-understandable" [15].

Gallie's understanding unveiled the importance and prestige of 'Critical Philosophy' of history that by applying various theories, methods and approaches, a reliable historical fact can be coined. He furthermore, insists on the proper historical narratives and supportive evidence [16]. Gallie referred the idea of William Dray, as he portrays the concept of 'Rational Explanation' which spectacles a vibrant role "in relation to historical narratives" [17]. Nevertheless, a historical narrative is qualified with the coherent historical explanation. This is to clear the visionary aspects of the past events and to recognize the domain of the stated accounts.

Hampel,[17] (1905-1997) in 1942 organizing the 'narratives', presented a universal method for the analysis of the history. He focused that historians should provide 'valid explanations' of past. Moreover, "By casting their narrative accounts in a form that is fundamentally the same as that employed by the natural sciences" [16]. Hampelian theory commended the historians towards scientific approaches and detailed accounts "to reclaim inclusion within the realm of true science...” [18] Basically, Hampel required more authenticity to measure the historical facts on scientific grounds. This scientific approach would refine the facts by 
removing the sentimental, sympathetic and compassionate buds on specific historical evidences.

While, David Carr discussed in detail the narrative accounts of history. He considered that narrative accounts are helpful to analyze the past events. "They are often said to be true life; that is to tell us how certain evens might have occurred if they have really happened" [19]. Some historians considered the "narrative history" merely based on fiction but currently improved and managed as "scientific history". Mink also considered the narrative approach of history as "mode of comprehension" and he seems defending this manner of narrative history. Consequently, Hemple endorsed the narrative history, as it is closer to reality and provides a widespread order of the occurred events. Sometimes, a single historical event provides various dimensions to differentiate many past events and clarifies the prevailing notions.

In historical methods, narration of events has its gravity in philosophy of history. This is convenient to perceive the past under a certain narrative process. Paul A. Roth compares the narrative history with storytelling or tale. He uttered that a historian must discover the happened events in a certain domain first and then try to find out how these events occurred to relate the events with each other. Paul emphasised that "once this research has been carried out forward to a partial conclusion, he must, of course, think about how he will best present his findings..." [20]. Finally, these results of the historical research give a new sense to the past-occurred events with some frequent dimensions.

Human beings perceive the history and historical events subjecting to their individual context to demarcate a conclusion. But steadily, there are several patterns of philosophy of history to nourish and clarify the rationale. Recollection and re-allocation is the very theme of historiography but philosophy of history has given the prospect to such rationale behind the historical data to evaluate it. In historical perspective, most of the human beings collected the information from certain memories but philosophy of history provides a dense platform to evaluate the memories according to the deeper proceedings of the time span under a certain theoretical domain of the historical framework, which braces the historical progression to increase the worth of history.

In this regard, Lord Acton (1736-1811) [21] weighs the history as a guide to affairs of the human life asserting present is based on past. "Human Development has been a continuous chain of cause and effect". He acknowledged the history as the "School Master of Action" [22]. Moreover, Acton managed the history as a 'valuable guide', because it serves human beings letting them learn from the blunders of their ancestors. The historical knowledge prevents us from the confusion of the past events. History is as well "sum of man's achievement" and "key to the destiny". Acton boards the historical process by following certain process and resolved the present based on past.

The method to analyze and measure the history is dominantly empirical and logical based. The empirical study is to frequently evaluate and symmetrize the chronological orders. This is accommodating to draw out the logics from the unsounded events of the past. This organization determines principles of the 'Historiography' to help out the historians to standardize the historical philosophy. So, the historiography in this regard has a main set-back as well. The historians followed merely certain conventional doctrines of the influential philosophers and intellectuals to reach the verdict on a historical event of the past. This can undermine the personal observations and logical strength of the contemporary historians during the evaluation of the primary and secondary data.

\section{E. H. Carr wrote [23]:}

"Historians of a later generation do not look forward to any such prospect. They expect their work to be superseded again and again. They consider that knowledge of the past has come down through one or more human minds, has been 'processed' by them, and therefore cannot consist of elemental and impersonal atoms which nothing can alter The exploration seems to be endless, and some impatient scholars take refuge in skepticism, or at least in the doctrine that, since all historical judgments involve persons and points of view, one is as good as another and there is no 'objective' historical truth".

Philosophy of history also kindled a certain sense of intuition and imaginational forces in historians, which mechanized through historiography. It lets the historians assess the past with inner most affiliation and dedication towards the historical matters. This intuitional intellect is important to feel the depth and to pledge the knowledge of the past regarding the experiences and achievements. The historiography and the "historical intuitions" have several differences. Ultimately, they appear on same pattern in the findings of the historical research. Likewise, a historian is the one who is destined to provide the exact details "to produce the right response in the reader". Occasionally, the historical readings by a historian can stimulate the anarchy unintentionally because readers perceive the context differently [3] .

These continuing developments and improvements under certain theoretical and practical frameworks determined by philosophy of history induce the worth of 'History'. Philosophy of History makes the past compatible with present and its implications with future. The worthwhile phenomenon of the 'History' more flourished when history as a subject became the part of academia. Scot Gordon, proved the History an "Intellectual Discipline”, History as a discipline developed progressively in 18th Century. According to Scot, this is the reason that now in a developed form, history is the part of social science in academia [24].

\section{REFERENCES}

[1] There are two common types of historians, independent and court historians. Court historian ever remains under the deep influence of the ruler to establish an official version of pro-ruler historiography. But independent historian ever establishes the historical account neutrally.

[2] E. H. Carr, What is History, 2nd Ed. England: 1 lil'J U UNBOOK, 1987, p. 29.

[3] S. Turner, "MindBlind philosophy of history," Journal for Philosophy of History, vol. 2, p. 232, 2008

[4] C. Brinton, "Lord acton's philosophy of history," The Harvard Theological Review, vol. 12, no. 1, p. 93, Jan. 1919.

[5] Department of Philosophy, University of California, USA.

[6] P. A. Roth, "Varieties and vagaries of historical explanation," Journal of Philosophy of History, vol. 2, p. 222, 2008. 
[7] W. Turner, History of Philosophy, Boston: Ginn \& Company, 1903, p. 654.

[8] P. A. Roth, "Varieties and vagaries of historical explanation," Journal of Philosophy of History, vol. 2, p. 223, 2008.

[9] D. Kipp, "What is philosophy of history," Indian Philosophical Quarterly, vol. 6, no. 2, p. 271, 1976

[10] W. H. Walsh, Philosophy of History: An Introduction, Revised Edition, New York: Harper \& Row Publishers, 1968, p. 20.

[11] E. H. Carr was an English journalist, thinker and IR theorist.

[12] E. H. Carr, What is History, p. 8.

[13] S. Gordon, History and Philosophy of Social Sciences, 2nd Ed. London: Routledge, 2003, p. 390

[14] W. B. Gallie was a Scottish thinker and political theorist.

[15] W. B. Gallie, Philosophy and the Historical Understanding, London: CHATTO \& WINDUS, 1964, p. 12.

[16] S. Gordon, History and Philosophy of Social Sciences, 2nd Ed. London: Routledge, 2003, p. 391.

[17] C. Gustav "Peter" Hampel was a German scholar and philosopher. In 1942 he presented The "Function of General Laws in History'.

[18] P. A. Roth, "A full hempel," History and Theory, vol. 38, no. 2, p. 249, May 1999.

[19] D. Carr, "Narrative and the real world: An argument for continuity," History and Theory, vol. 25, no. 2, p. 117, May 1986.

[20] P. A. Roth, "Narrative explanations: The case of history," History and Theory, vol. 27, no. 1, p. 4, Feb. 1988.

[21] Sir John Acton was the commander of the naval forces and prime minister of Naples.

[22] C. Brinton, "Lord Acton's philosophy of history," The Harvard Theological Review, vol. 12, no. 1, p. 87, Jan. 1919.

[23] The New Cambridge Modern History, sighted in E. H. Carr, What is History, 7.8 .
[24] S. Gordon, History and Philosophy of Social Sciences, 2nd Ed. London: Routledge, 2003, pp. 390-391.

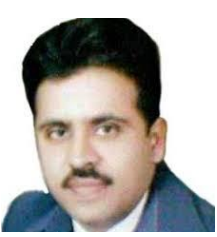

Busharat Elahi Jamil was born in Rabwah, Dist. Chiniot, Pakistan on September 30, 1977. He is MA in Political Science, MA in History from University of the Punjab Lahore, Pakistan and M. Phil in History from Government College University, Lahore, Pakistan. He is a $\mathrm{PhD}$ (History) research Scholar from Government College University, Lahore, Pakistan (only the viva is remaining).

He has served Forman Christian College (A Chartered University) Lahore, Pakistan for more than 10 years as Lecturer and Assistant Prof. Moreover; he also remained advisor Griswold History Society of Forman Christian College University for 3 years. He is the author of various research publications e.g. "Sikh Dilemma: The Partition of Punjab 1947", "Master in Partition: Antagonistic Character of Master Tara Singh in the Partition of Punjab 1947", "Punjab Disruptions: An Account on Massive Disorder in Punjab, January-August 1947" and "Muslim Politics and the Partition of the Punjab 1940-1947" and many others. $\mathrm{He}$ is also contributing articles, columns and book reviews in various national and international journals, magazines and newspapers like Daily Times, Lahore International and Pakistan Times USA etc.

Mr. Jamil is the member of the Editorial Board of the "Lyallpur Historical and Cultural Research Journal", Member technical committee IEDRC international Conference, San Francisco USA October 2016, Member Selection Board (History) Government College University, Faisalabad, Pakistan and also served as external examiner, Member Board of Study and external examiner (History) University of Sargodha, Sargodha, Pakistan. He is also co-supervisor of various M. Phil theses Department of History university of Sargodha, Pakistan 